\title{
Investigating the Effect of Mobile Apps on Student's Motivation and Achievement in Motor Vehicle Mechanic Work
}

\author{
Ike Joshua Onyedikachi ${ }^{1}$, Ariyo Samson Oluwatimilehin ${ }^{2}$, Olawale Olaitan Opeyemi ${ }^{3}$ \\ ${ }^{I}$ M.Tech, Department of Industrial Technical Education, Faculty of Vocational and Technical \\ Education, University of Nigeria, Nsukka.Nigeria.E-mail: joshua.ike@unn.edu.ng \\ ${ }^{2}$ Ph.D., Department of Industrial Technical Education, Faculty of Vocational and Technical \\ Education, University of Nigeria, Nsukka, Nigeria.E-mail: samson.ariyo@unn.edu.ng
}

${ }^{3}$ Ph.D., Department of Industrial Technical Education, University of Nigeria, Nsukka, Nigeria.

E-mail: olawale.olaitan@unn.edu.ng

\begin{tabular}{|c|c|}
\hline Articl & Abstract \\
\hline Articl & Purpose: The study was carried out to investigate the effect of mobile apps \\
\hline September 2020 & on students' achievement in petrol engine maintenance work in technical \\
\hline Revise & colleges in Enugu State, Nigeria. \\
\hline & $\begin{array}{l}\text { Approach/Methodology/Design: The study adopted quasi-experimental } \\
\text { design and was carried out in Enugu State, Nigeria. The population for the }\end{array}$ \\
\hline Key & study was 170 NTC II students. The sample size for the study was 40 motor \\
\hline 1 Education, & vehicle mechanics work NTC II students who have any mobile technologies \\
\hline Technical Colleges, & (Smart phones) participated in the experimental group and were selected \\
\hline $\begin{array}{l}\text { Achievement, } \\
\text { Curriculum. }\end{array}$ & using purposive sampling technique. The instrument for data collection was \\
\hline & $\begin{array}{l}\text { motor vehicle mechanic work achievement test }(M W M W A T) \text {. The data } \\
\text { collected were analyzed using mean, to answer the research questions while } \\
\text { ANCOVA was used to test the hypothesis. Three research auestions were }\end{array}$ \\
\hline & $\begin{array}{l}\text { answered, while one null hypothesis formulated were tested at } 0.05 \text { level of } \\
\text { significance. }\end{array}$ \\
\hline Reser & $\begin{array}{l}\text { Findings: The study revealed that students taught petrol vehicle } \\
\text { maintenance works with mobile apps had a higher mean achievement score }\end{array}$ \\
\hline Corresponding Author: & $\begin{array}{l}\text { than those students taught using conventional teaching aids in the } \\
\text { achievement test. There was a significant difference between the mean }\end{array}$ \\
\hline & achievement scores of students taught with mobile apps and those taught \\
\hline Oluwatimilehin & $\begin{array}{l}\text { with conventional teaching aids in motor vehicle mechanics work trade. } \\
\text { Practical Implications: The study will contribute positively to the }\end{array}$ \\
\hline $\begin{array}{l}\text { Email: } \\
\text { samson.ariyo }\end{array}$ & $\begin{array}{l}\text { understanding of using mobile apps to increase students' motivation and } \\
\text { academic achievement. }\end{array}$ \\
\hline & $\begin{array}{l}\text { Originality/value: This study innovates in examining the use of mobile apps } \\
\text { by motor vehicle mechanic work teachers in improving the motivation and } \\
\text { academic achievement of students. }\end{array}$ \\
\hline
\end{tabular}

\section{Introduction}

Mobile applications (apps) are software programs that students can download and access directly using their phone or another mobile device like a tablet. A Mobile app is built for a smaller handheld display and touch-screen interfaces. According to Mashable (2012), mobile apps are actual applications that are downloaded and installed on the mobile device, rather than being rendered within a browser. 
Users visit device-specific portals such as Apple's Application Store for iOS (Apple iphones), Android Google play store for Smart phones that runs on android Operating Systems (OS) or Blackberry Application World for Blackberry mobile device to find and download apps for a given operating system for specific applications. The application may pull content and data from the Internet, similar to a website, or it may download the content so it can be accessed without an Internet connection. Mobile apps have provided an entirely new distribution mechanism for content, stimulating substantial investment in software development for mobile devices. The uses of these mobile apps in modern times are many and diverse, their relevance in contemporary period have now permeated the educational systems as tools in teaching and learning as well as improving students' academic achievement.

Students' achievement is quantified by a measure of the students' academic standing in relation to those of other students of his age (Anene, 2005). Students' achievement is dependent upon several factors among which are instructional method, the use of instructional materials and learning environment (Atherson, 2013). Achievement with respect to this work is the learning outcomes of the students which is the knowledge acquired through his course of study within and outside the classroom situations. Students learn best when they are involved, motivated and appropriately challenged by their work.

Motivation in the view of Nnachi (2009) refers to forces acting on or within an individual to cause, initiate or direct behaviors. Onwuamunam (2012) viewed motivation as an individual urges, desire tendency or striving to achieve a goal or fulfil certain needs. Motivation is the key to success and a driving force by which students achieve their goals in teaching and learning process. Smart mobile technology are expanding the learning experiences through educational apps both inside and outside the classroom, making it more interactive, immersive and engaging: thus when students are more engaged, they are more motivated and they performed better.

\section{Literature Review}

Educational applications are type of mobile applications for specific application that has provided new tools for educational activities such as annotation, calculation, composition and content creation (Brain, 2014). While a small number of educational applications are mapped to curriculum targets and designed for use in classroom or homework settings, the majority are intended mainly for informal learning (Regin \& Haeng-Kon 2014). However, as more students use mobile devices in formal education settings, mobile applications will likely become an important part of the mobile learning system.

Educational applications are expanding the learning experience both inside and outside the classroom, making it more interactive, immersive, and engaging. With so many educational applications available and more being developed all the time, there's no limit to the exciting possibilities for learning (McKinsey, 2012). Tens of thousands of education applications on the Google play store cover everything from math and science to engineering and technology 
which include motor vehicle maintenance work. Most importantly, teachers of motor vehicle maintenance work can deliver engaging lessons using these educational applications installed on mobile devices such as the Smart phones as instructional materials, to monitor the progress, get immediate feedback on students, and stay organized. Educational applications help the students to be more engaged, motivated and perform better (Bobo, 2013). Educational applications are designed with educational purposes and they have secondary educational value. Some of which includes automobile engineering applications.

Automobile engineering applications are designed to teach students about automobile subject/motor vehicle mechanic works, expand concepts, reinforce development, understand an historical event or assist the students in learning (Rajput, 2010). Automobile engineering applications have latest and advanced videos of vehicles and engines parts for learning courses. It provides educational applications for students and teachers, makes learning to be fun, trains' memory and improves knowledge.

Motor vehicle mechanics work is one of the automobile trades offered in Nigeria technical colleges (Federal Republic of Nigeria, 2013). The programme for Motor Vehicle Mechanics (MVM) work in Nigeria Technical Colleges comprises of five modules at the NTC level which includes: service station mechanic, petrol engine maintenance, diesel engine maintenance, refurbishing works and auto-electricity/electronic designed to produce competent motor vehicle craftsmen for self-reliant and national development. This study is focused on petrol engine maintenance work with emphasis on basic operations of crankshaft, camshaft, connecting rod, piston and piston rings. Graduates of motor vehicle mechanic work from technical colleges according to the National Board for Technical Education NBTE (2004) are to inspect, identify problems, repair and service mechanical, electrical and electronic system and components of vehicles. In Enugu State, the percentage analysis of candidates that failed in May/June 2010-2014 NBC/NTC NABTEB Examinations in motor vehicle mechanics trades (020) are: 83.8, 95.6, 63.9, 75.6 and 59.6 percent, respectively (Olatunde, 2014). Poor achievements of students in motor vehicle mechanics trades have been attributed to a number of factors which include among others teaching methods/techniques, inadequate instructional materials/strategies.

Academic achievement is the general ability of the students concerning their offered subjects compared to a specified standard called pass marks (Abubakar, 2013). Achievement in Motor Vehicle Mechanic Works connotes performance in the school subject as symbolized by a score or mark on motor vehicle mechanic works achievement test. Students learn best when they are involved, interested and appropriately challenged by their work. Teachers with good instructional methods and instructional materials challenge students to work at advanced logical height which helps to increase the learners' achievement when motivated.

Motivation refers to forces acting on or within an individual to cause, initiate or direct behaviours (Abu, 2014). He further explained that motivation is a prime factor in human success era job and it is by means of motivation that an action is taken to reach a goal. 
According to Colman (2003), motivation is a driving force or forces responsible for initiation, persistence, direction and vigour of goal directed behaviours. It is the key to success and a driving force by which humans achieve their goals in an occupation. Teachers of motor vehicle mechanic work can as well enhance student's achievement during teaching and learning when appropriate motivational strategies are incorporated.

Unfortunately, the common instructional materials that teachers of motor vehicle mechanic work prefer today at the technical college is the use of chart containing the diagrams of the components to be taught (Regin \& Haeng-Kon, 2014). In the process of using this instructional material, the teacher transmits knowledge to the students who sit passively in the classroom and listen. Another advance instructional material is the real objects which were adopted in order to avoid the boredom of passive learning and to provide a more efficient learning environment.

However, the use of chart as an instructional materials used by the teachers of motor vehicle mechanic work is considered inadequate and results in poor achievement among these students. The use of mobile devices as instructional material will enable the students to access what they have learnt, anytime, anywhere as well as motivates them in learning (Sonmez, 2011). Olaitan, et al. (2009) have stressed the need to modify instructional strategies to incorporate the techniques that would establish a firm foundation for acquisition of both knowledge and skills which are necessary steps for technological capacities and positive instructional development to enhance achievement.

The purpose of the study is to investigate the effects of mobile technology applications on student's achievement in petrol engine maintenance works in technical colleges in Enugu State. Specifically, the study will seek to determine:

1. The mean achievement scores of students taught crankshaft operations/camshaft mechanism with mobile technology applications and the mean achievement scores of students taught without mobile application.

2. The mean achievement scores of students taught operations of the connecting rod with mobile technology applications and the mean achievement scores of students taught without mobile application.

3. The mean achievement scores of students taught fixing and operations of piston/ piston rings with mobile technology applications and the mean achievement scores of students taught without mobile application.

$\mathrm{HO}_{1}$ : There is no significant difference in the mean achievement scores of motor vehicle mechanic trade students taught with mobile applications in petrol vehicle maintenance works and those taught with conventional teaching aids.

\section{Methodology and Procedures}


A quasi-experimental design was adopted for this study. Quasi-experimental design according to Gall, Gall and Borg (2007) is employed when it is not possible for the researcher to randomly sample the subject and assign them to treatment groups (experimental and control groups) without disrupting the academic programmes of the schools involved in the study. The study was conducted in Enugu state. Enugu State has many NBTE accredited Technical Colleges offering motor vehicle mechanics work, whose students participated in the study. The study was conducted in four Technical Colleges; Government Technical College Nsukka, Government Technical College Enugu, Government Technical College, Achi and Umuitodo Technical College Obollo-Orie, Udenu L.G.A because of their level of exposure/acquisition to this mobile technology.

The population for this study consists of 170 NTC II students of motor vehicle mechanics work in the four selected Technical Colleges in Enugu State that offers motor vehicle mechanics work in the state. The sample size for the study was 104 NTC II students: 55 students who have any of these mobile technologies/gadgets participated in the experimental group which comprised 32 students from GTC Enugu and 23 students from GTC Nsukka while the other 49 comprised 28 students from GTC Achi and 21 students from UTC ObolloOrie was used as control group (students who do not have any of these mobile technologies/gadgets).

A purposive sampling technique was used for selection of student's from the four Technical Colleges for this study. Purposive sampling, according to Nworgu (1991), is a sampling technique in which specific elements are selected because they satisfy some pre-conditioned criteria, and because of administrative base of data collection. Thus from all the four technical colleges that offers motor vehicle mechanic work in the State, those that possesses these mobile devices were purposively selected. Intact classes in each college were used for the study such that all the students can benefit from the lesson. NTC II motor vehicle mechanics work students in the four colleges were the subjects of the study.

The instrument for data collection was Motor Vehicle Mechanics Work Achievement Test (MVMWAT). The MVMWAT instrument was adapted from National Business and Technical Examination Board (NABTEB) past question papers. The content of the adapted questions covered the syllabus of the class chosen for the study. MVMWAT was a 20 multiple choice items with four options drawn from petrol engine maintenance, diesel engine maintenance, refurbishing and service station mechanics module. The construction of test item was based on NBTE MVMW trade curriculum and table of specifications. The researcher prepared lesson plan for the teaching of these modules. The lesson plan was prepared from the units in the test blue print. It contains four lesson plan that lasted for a period of four weeks. The researcher took into consideration the age, class of the students, the sixty minutes duration, the specific objectives and their relation to the lesson topics in preparing the lesson plans. The MVMWAT was validated by three experts, one motor vehicle mechanic work teacher from GTC-Nsukka and two lecturers from mechanical section of the Department of Industrial Technical Education, University of Nigeria, Nsukka. The face 
validation involved checking the MVMWAT items of the instrument for arrangement and logical sequence and the content validation involved the validators confirming/ensuring that the content of the instrument were in agreement with the course content. The comments and suggestions on the instrument by the validators were incorporated into the final draft of the instrument. A trial test of the instrument was carried out for the purpose of determining the coefficient of stability of the MVMWAT using test retest reliability technique. The instrument was administered on ten NTC II motor vehicle mechanic work technology students in GTC Abakiliki, Ebonyi State. The objective answer sheets were marked by the researcher and score kept. After two weeks, MVMWAT was re-administered to the same sample at GTC Abakiliki in Ebonyi State. The objective answer sheet were also marked by the researcher and scores obtained. The first and second scores of the test were correlated. The reliability coefficient of the MVMWAT was determined using Pearson product moment correlating coefficient. Reliability coefficient of 0.91 was gotten showing that MVMWAT was stable. Few days briefing were conducted by the researcher. The teachers were given detailed explanation on the use of mobile based instructional applications and other research expectations. The briefing was based on the purpose of the study, the topics to taught, the use of the lesson plans and general conduct of the study. After briefing of the teachers, pre-test was given to the students before teaching began.

The conduct of the study took place during the normal school lesson periods. The normal time table of the schools used for the study was followed. The regular school MVMW teachers were used as research assistance. The teachers used the lesson plan to teach the students. Each lesson plan lasted for sixty minutes and entire process lasted for four weeks. At the end of the process, a post-test was administered with the MVMW .The data collected from the administration of pre-test and post-test of learning were analysed using mean to answer the research questions. The pre-test and post-test mean gain of the students was compared to determine the main effect of the treatment of the mobile technology application (motor vehicle mechanics apps) on students' motivation and achievement in petrol engine maintenance works. The null hypothesis was tested using Analysis of Covalence (ANOVA) at 0.05 level of significance. The use of ANOVA was to control the errors of the initial non equivalence arising from the use of intact classes as subject of the study. Also with the use of ANCOVA the pre-test result serve as covariant of the post-test result so as to block the effect of covariant on the post-test.

\section{Results and Discussion}

Table 1: Mean achievement scores of students taught with mobile applications in crankshaft operations/ camshaft mechanism.

\begin{tabular}{lllll}
\hline Group & $\mathrm{N}$ & $\frac{\text { Pre-test }}{\mathrm{X}}$ & $\frac{\text { Post-test }}{\mathrm{X}}$ & Mean Gain \\
\hline Experimental & 40 & 4.33 & 14.33 & 10.00 \\
Control & 60 & 3.13 & 9.13 & 6.00 \\
\hline
\end{tabular}

Sources: Authors 
The data presented in Table 1 shows that the experimental groups taught crankshaft operations with mobile technology applications had a mean achievement score of 4.33 in the pre-test and a mean achievement score of 14.33 in the post-test making a pre-test, post-test mean gain in favour of experimental group to be 10 .

The control group taught crankshaft operations with conventional teaching aids had a mean achievement score of 3.13 in the pre-test and a post-test mean achievement sore of 9.13 with a pre-test, post-test mean gain of 6 . With this result, the students in the experimental group performed better in the achievement test than the students in the control group.

Table 2: Mean achievement scores of students taught with mobile applications in operations of the connecting rod.

\begin{tabular}{lllll}
\hline Group & $\mathrm{N}$ & Pre-test & Post-test & \\
& & $\mathrm{X}$ & $\mathrm{X}$ & Mean Gain \\
\hline Experimental & 40 & 4.55 & 24.55 & 20.00 \\
Control & 60 & 4.18 & 14.18 & 10.00 \\
\hline
\end{tabular}

Sources: Authors

The data presented in Table 3 shows that the experimental groups taught operations of the connecting rod with mobile technology applications had a mean achievement score of 4.55 in the pre-test and a mean achievement score of 24.55 in the post-test making a pre-test, posttest mean gain in experimental group to be 20.00 .

The control group taught operations of the connecting rod with conventional teaching aids had a mean achievement score of 4.18 in the pre-test and a post-test mean achievement sore of 14.18 with a pre-test, post-test mean gain of 10.00 . With this result, the students in the experimental group performed better in the achievement test than the students in the control group.

Table 3: Mean achievement scores of students taught with mobile technology applications in fixing and operations of piston/ piston rings.

\begin{tabular}{lllll}
\hline Group & $\mathrm{N}$ & Pre-test & Post-test & \\
& & $\bar{X}$ & $\bar{X}$ & Mean Gain \\
\hline Experimental & 40 & 4.60 & 24.60 & 20.00 \\
Control & 60 & 2.78 & 12.78 & 10.00 \\
\hline
\end{tabular}

Sources: Authors

The data presented in Table 5 shows that the experimental groups taught inserting of piston rings with mobile technology applications had a mean achievement score of 4.60 in the pretest and a mean achievement score of 24.60 in the post-test making a pre-test, post-test mean gain in experimental group to be 20.00 . The control group taught inserting of piston rings with conventional teaching aids had a mean achievement score of 2.78 in the pre-test and a post-test mean achievement sore of 12.78 with a pre-test, post-test mean gain of 10.00 . With this result, the students in the experimental group performed better in the achievement test than the students in the control group. 


\section{Testing of Hypotheses}

HO1: There is no significant difference in the mean achievement scores of motor vehicle mechanic trade students taught with mobile technology applications in petrol vehicle maintenance works and those taught with conventional teaching aids.

Summary of Analysis of Covariance (ANCOVA) for Test of Significance between the Mean Score of Experimental and Control Groups in the MVMW Achievement Test

\begin{tabular}{llllll}
\hline Source & Sum & of & Mean & & \\
Corrected Model & Squares & Df & Squares & F & Sig. \\
Intercept & $2620.383^{\mathrm{a}}$ & 2 & 1310.192 & 110.660 & .000 \\
Pre-test & 318.009 & 1 & 318.009 & 26.859 & .000 \\
Groups & 1585.477 & 1 & 1585.477 & 133.911 & .000 \\
Error & 730.455 & 1 & 730.455 & $61.695^{*}$ & .000 \\
Total & 1148.457 & 97 & 11.840 & & \\
Corrected Total & 30862.000 & 100 & & & \\
\hline Signican & 3768.840 & 99 & & & \\
\hline
\end{tabular}

Significant at Sig of $\mathrm{F}<0.05$

Sources: Authors

The analysis of data presented in the above table shows that F-value for the experimental group (mobile app) is 61.695 with a significance of $\mathrm{F}$ at .000 , which is less than 0.05 alpha value at which it is been tested. The null hypothesis of no significant difference was therefore rejected at 0.05 level of significance. With these results, there is a significant difference between the main effect of treatments on students' achievement in the petrol engine maintenance works.

The findings reveal that students taught Petrol Engine Maintenance Works (PEMW) with mobile technology applications had a higher mean achievement score than those students taught using the conventional teaching aids in the achievement test. In the same vein, analysis of covariance was used to test the hypothesis, at the calculated F-value 61.695 at significance of $F(.000)$ and confidence level of 0.05. There was statistically significant difference between the mean scores of the group taught with mobile technology application and those taught using the conventional teaching aids in the achievement test. The implication of this finding therefore is that mobile app as an instructional material is more effective than conventional teaching aids (chart, real objects) in enhancing students' achievement in petrol engine maintenance works. The finding agreed with the finding of Selami (2013) who conducted a study on mobile based instruction application: the effect of mobile-based concept instruction on academic achievement, retention and attitudes of students and found that students taught with mobile technology (smart phones) performed better than those taught without mobile technology.

This finding agreed with the finding of Jabbour (2013) who found out that there was a significant difference in the educational foundations achievement of experimental group 
taught with mobile technologies/computer aided instruction and control group taught with conventional teaching aids in favour of the experimental group. Bakac, Tasoglu\&Tkbay (2011) in their study on effects of computer assisted instruction with simulation on students' success in electric current activities, also found out that the use of CAI in teaching electric current improved students' achievement in the subject than the students taught electric current with traditional instructional aids.

Mobile apps as an institutional material enhance how students learn by supporting four fundamental characteristic of learning: active engagement, participation in groups, connections to real-world context, frequent interaction/feedback (Dede, 2015). Owing to the dominance of the teacher in the traditional teaching approaches using chart, real object, students are not engaged in the classroom activities because such interactive environment is not provided.

In learning, providing opportunities to interact with course material through the use of interactive mobile apps tends to change the course from teacher-centered approach to one that is more student-centered and focused on the cognitive development and construction of knowledge in the students (Lajoie, 2014). Hence, one means of constructing knowledge is to create meaning by doing and interacting. Creating support for knowledge construction within the students is a critical component to the success of developing self-motivation, intellectually stimulated learners. Paul (2013) argues that students can learn to think better if schools concentrate on teaching how to do so, through the use of appropriate instructional techniques, which will promote intellectual growth and fosters academic achievements/performance gains in our rapid technological changing world.

Instructional teaching material, such as the use of mobile apps, provides the students with an interactive learning environment which invariably creates meaningful learning activities. Meaningful learning activities built on prior knowledge motivate students and foster their retention in their effort to executively control their own cognitive process.

\section{Conclusion and Suggestion}

Motor vehicle mechanic works is one of the trade subject found in technical colleges to equip students with knowledge, skills and attitude for self-reliance. However, the performance of graduates and learning outcomes of the students in MVMW over the years are not encouraging. This problem is now tied to the kinds of teaching strategies and teaching aids used for implementing the trade. In order to proffer solution to the identified problem, a study now set up to investigate the effects of mobile technology applications on students' achievement in petrol engine maintenance works in technical colleges. The investigation therefore reveals that teaching petrol engine maintenance works to students using mobile technology application is better than employing other conventional teaching aids (chart, real objects). 
Based on the findings, the following recommendations were made:

1. Motor vehicle mechanic work teachers in technical colleges should adopt the use of the mobile technology applications to teach motor vehicle mechanic work trades to students.

2. Facilities that could encourage the use of mobile technology should be provided to the motor vehicle mechanic work teachers in the technical colleges.

3. Workshop and seminar should be organized for motor vehicle mechanic work teachers on the effective use of mobile technology applications.

4. The use of conventional teaching aids (chart, real objects) should be discouraged among the teachers who teach motor vehicle mechanic work students.

5. Student should always be allowed to actively and interact freely with the teachers and their peers in the class with their mobile devices as this will improve academic gain in the subjects.

\section{Conflict of Interest}

The authors of the article declare no conflict of interest.

\section{Funding}

This research study was not funded by any institution. The author conducted the study on their own expenses.

\section{References}

Abu, M.(2014). Development of Motivational Training Programme for Enhancing the Entry of Almajiris into Cotton Production Occupations in Northwest, Nigeria.Unpublished Ph.D. dissertation, Department of Vocational Teacher Education, University of Nigeria, Nsukka.

Abubakar, D. (2013). Maintenance technology and productivity.Journal on Productivity Improvement.National Productivity Centre, 24(6) 8-16.

Anene, G.U. (2005). Home economics and the academic performance of a child. Journal of Home Economics Research, 6(1) 99 - 103.

Atherson, J.S. (2013). Learning and teaching intelligence. Retrieved February, 20, 2014. http://www.dmu .ac.uk/jamesa/learningintellig.htm.

Bobo, E. L. (2013). Apps in the Classroom: Using Ios Apps for Teaching and Learning www.apple.com/itunes/what-is" Apple Inc

Brain, P. O. P, (2014). IPad in Education: Evaluating Apps for the Classroom. www.apple.com/itunes/features. Apple Inc

Colman, A. M (2003).Oxford Dictionary of Psychology. Oxford: Oxford University Press.

Gall, M.D., Gall J.O., \& Borg W.R. (2007). Educational research: An introduction. Boston: Pearson Edu.Inc.

Federal Republic of Nigeria (2013). Technical and vocational education development in Nigeria in the $21^{\text {st }}$ century with the blue-print for the Decade 2001-2010. Abuja: Federal Ministry of Education. 
Mashable, A. (2012). What developers can learn from top mobile appshttp://mashable.com/2012/08/08/top-mobile-apps-design/\#081Hefk59iql

McKinsey (2012). The impact of technology and analytics on the education industry in Regin J. C. \&Haeng-Kon K. (2014). The effect of the future mobile learning: current state andfuture opportunities. International Journal of Software Engineering and Its Applications.8 (8) 193-200.http://dx.doi. org/10.14257/ijseia.2014.8.8,18

National Board for Technical Education (2004). Motor vehicle mechanics trades:http://www.nbte.gov.ng/programme.html.pdf. Retrieved 2016.

Nnachi, R. O. (2009) Advanced Psychology of Learning and Scientific Enquiries. Abuja: Totan Publishers.

Olaitan, S.O., Nwachukwu, C.E., Igbo C.A., Onyemachi, G.A. \&Ekong, A.O. (2009). Curriculum development and management in vocational technical education. Onitsha: Cape Publisher.

Olatunde, A. A. (2014). Why candidates fail in public examinations, fed. Ministry of education. National stakeholders consultative meeting on improving performance in public examination at the National Universities Commission NUC, Abuja.

Owuamunam, D. O. (2002) Fundamentals of Educational Psychology. Lagos: Bolabay Publishers.

Rajput, R. K. (2010). A textbook of automobile engineering. New Delhi: Laxmi Publications Limited.

Regin J. C.,\&Haeng-Kon K. (2014).Digital textbooks and E-Readers. The effect of the future mobile learning: current state andfuture opportunities. International Journal of Software Engineeringand Its Applications.8 (8) 193-200. http://dx.doi.org/10.14257/ijseia.2014. 8.8,18

Sommez, A. M. (2011). Mobile learning: research to practice to impact education. Learning and Teaching in Higher Education: Gulf Perspectives, 10(2). 